\title{
COVID-19 infection presented as severe dyskinesia in a patient with Parkinson's disease: a case with daily video recording
}

\author{
Murat Gultekin ${ }^{1}(1) \cdot$ Zeynep Tufekcioglu² $^{2}$
}

Received: 12 January 2021 / Accepted: 19 January 2022 / Published online: 8 February 2022

(c) Fondazione Società Italiana di Neurologia 2022

The impact of the current coronavirus disease 2019 (COVID19) infection on motor complications of Parkinson's disease (PD) is not fully characterized. Deterioration of motor and non-motor symptoms was demonstrated in a limited number of studies $(1,2)$. However, increased daily off time and motor disability causing increase in dopaminergic therapy were reported in $30-50 \%$ of PD patients with COVID-19 infection, and severe dyskinesias causing decrease or cessation in dopaminergic therapy have not been reported yet. Here we present a patient with PD who had severe peak dose dyskinesias due to acute COVID-19 infection.

A 75-year-old man admitted to our outpatient clinic with complaints of sudden severe peak-dose dyskinesias and fatigue appeared in the last 3 days. He had 4-year history of PD with no other past medical history. He was fully independent in carrying out daily living activities and had no cognitive involvement. Hoehn and Yahr score was 3. He was suffering from motor fluctuations with motor off periods within 1 year; however, he did never experience dyskinesias before. He was treated with levodopa/benserazide $100 / 25 \mathrm{mg} 6 \times 1 /$ day and pramipexole $3 \mathrm{mg} /$ day. In his neurological examination, he had severe generalized dyskinesias (Video 1). The patient had generalized pain and intense fatigue. He was inclined to sleep and apathic. His skin was not sweaty, he had a dry mouth, and his body temperature was measured as $37.2^{\circ} \mathrm{C}$. Blood tests (biochemistry tests and hemogram) were within normal limits. Because of the COVID-19 outbreak, he was evaluated for COVID-19 infection and the diagnosis was performed according to the World Health Organization (WHO) criteria (3). The loading dose of $3200 \mathrm{mg}$ /day favipiravir was administered on day 1 and

Murat Gultekin

gultekin@erciyes.edu.tr

1 Department of Neurology, Faculty of Medicine, Erciyes University, Talas Street, 38039 Kayseri, Turkey

2 Department of Neurology, Faculty of Medicine, Istanbul Aydin University, Sefakoy, 34295 Istanbul, Turkey followed by a maintenance dose of $1200 \mathrm{mg}$ /day for antiviral therapy (Table 1). All dopaminergic treatments were ceased and dyskinesias improved after $10 \mathrm{~h}$ (Video 2).

On the second day of antiviral treatment, body temperature was increased to $37.8^{\circ} \mathrm{C}$. There was a slight increase in general fatigue. His appetite decreased and his sleepiness increased. Although dyskinesia improved, we started levodopa/benserazide 100/25 mg $3 \times 1$ /day again; however, dyskinesias re-emerged with the first dose of the medication (Video 3). On the third day of antiviral treatment, his systemic and neurological examination did not change. There was a further increase in fatigue (Video 4). On the fourth day, the patient suddenly died because of cardiac acute heart attack.

There is limited data about the outcomes of PD patients with COVID-19 disease. They almost required additional levodopa due to severe motor dysfunction. Antonini et al. presented 10 PD patients with COVID-19 infection. Half of them required increase in levodopa dosage; however, none of them required decreasing (1). Similarly, a communitybased case-control study revealed worsening of levodoparesponsive motor symptoms and increased daily off time in 12 PD patients with COVID-19 infection (2). Although there was a tendency toward increased dyskinesia scores, it was not statistically significant and patients were not evaluated during active infection. Erro et al. reported two PD cases with severe dyskinesias after administration of SARS-CoV2 mRNA vaccine and suggested that immune response triggered by the vaccine might increase the permeability of blood-brain barrier and drug availability, thus causing the genesis of levodopa-induced dyskinesia (4). However, these cases did not have active infection; we suggested that similar immune responses might be triggered by acute COVID-19 infection in our case.

Clinicians are familiar of the fact that a subacute worsening of motor symptoms may be experienced following the systemic infections in PD. However, several different mechanisms may be involved in deterioration; the underlying 
Table 1 The progression of the motor complications and treatment approaches during COVID-19 infection

\begin{tabular}{|c|c|c|c|c|c|}
\hline Day & Neurological examination & Treatments & Clinical approaches & Laboratory tests & Video \\
\hline \multicolumn{6}{|c|}{ Before admission to outpatient clinic } \\
\hline 1st day & $\begin{array}{l}\text { Severe generalized dyskine- } \\
\text { sias during all day long }\end{array}$ & $\begin{array}{l}\text { L-dopa/benserazide } \\
100 / 25 \mathrm{mg} 6 \times 1 / \text { day } \\
\text { Pramipexole ER } 3 \mathrm{mg} 1 \times 1 / \\
\text { day }\end{array}$ & & & \\
\hline 2nd day & $\begin{array}{l}\text { Severe generalized dyskine- } \\
\text { sias during all day long }\end{array}$ & $\begin{array}{l}\text { L-dopa/benserazide } \\
100 / 25 \mathrm{mg} 6 \times 1 / \text { day } \\
\text { Pramipexole ER } 3 \mathrm{mg} 1 \times 1 / \\
\text { day }\end{array}$ & & & \\
\hline \multicolumn{6}{|c|}{ Admission to outpatient clinic } \\
\hline 3rd day & $\begin{array}{l}\text { Severe generalized dyskine- } \\
\text { sias during all day long }\end{array}$ & $\begin{array}{l}\text { L-dopa/benserazide } \\
100 / 25 \mathrm{mg} 6 \times 1 / \text { day } \\
\text { Pramipexole ER } 3 \mathrm{mg} 1 \times 1 / \\
\text { day }\end{array}$ & $\begin{array}{l}\text { Dopaminergic medications } \\
\text { stopped }\end{array}$ & COVID-19 PCR: positive & Video 1 \\
\hline \multirow[t]{2}{*}{ 4th day } & $\begin{array}{l}\text { Left side dominant parkinson- } \\
\text { ism with no dyskinesias } \\
\text { revealed after } 10 \mathrm{~h} \text { of medi- } \\
\text { cation cessation }\end{array}$ & Favipiravir $200 \mathrm{mg} 2 \times 8 /$ day & $\begin{array}{l}\text { L-dopa/benserazide } \\
100 / 25 \mathrm{mg} 3 \times 1 / \text { day started } \\
\text { when dyskinesias improved } \\
\text { and parkinsonism revealed }\end{array}$ & & Video 2 \\
\hline & $\begin{array}{l}\text { Generalized dyskinesias re- } \\
\text { appeared after first dose of } \\
\text { L-dopa }\end{array}$ & $\begin{array}{l}\text { L-dopa/benserazide } \\
100 / 25 \mathrm{mg} 3 \times 1 / \text { day } \\
\text { Favipiravir } 200 \mathrm{mg} 2 \times 8 / \text { day }\end{array}$ & & & Video 3 \\
\hline 5th day & $\begin{array}{l}\text { Generalized dyskinesias dur- } \\
\text { ing all day long }\end{array}$ & $\begin{array}{l}\text { L-dopa/benserazide } \\
100 / 25 \mathrm{mg} 3 \times 1 / \text { day } \\
\text { Favipiravir } 200 \mathrm{mg} 2 \times 3 / \text { day }\end{array}$ & & & Video 4 \\
\hline 6th day & $\begin{array}{l}\text { Generalized dyskinesias dur- } \\
\text { ing all day long }\end{array}$ & $\begin{array}{l}\text { L-dopa/benserazide } \\
100 / 25 \mathrm{mg} 3 \times 1 / \text { day } \\
\text { Favipiravir } 200 \mathrm{mg} 2 \times 3 / \text { day }\end{array}$ & & & \\
\hline 7th day & Generalized dyskinesias & $\begin{array}{l}\text { L-dopa/benserazide } \\
100 / 25 \mathrm{mg} 3 \times 1 / \text { day } \\
\text { Favipiravir } 200 \mathrm{mg} 2 \times 3 / \text { day }\end{array}$ & $\begin{array}{l}\text { He died due to acute myocard } \\
\text { infarction }\end{array}$ & & \\
\hline
\end{tabular}

Abbreviations: COVID-19, coronavirus disease 2019; PCR, polymerized chain reaction

mechanisms are still unknown (5). Changes in pharmacodynamics of dopaminergic drugs, the effects of systemic inflammatory responses, altered dopamine metabolism in the brain, and increased levels of stress during the infections are thought to be possible mechanisms $(5,6)$. Despite these hypotheses, emerging dyskinesia due to acute infection is a very rare condition in PD. However, the possible underlying mechanisms are unknown; individual immunological profiles should alter the responses. Consequently, clinicians should be aware of acute COVID-19 infection that could be presented as new onset severe dyskinesias in patients with PD.

Supplementary Information The online version contains supplementary material available at https://doi.org/10.1007/s10072-022-05912-4.

Acknowledgements We thank to our patient and his relatives who participated in our case report.

Author contribution Conception and design of the work: MG, ZT ZT

Acquisition, analysis, and interpretation of data for the work: MG,
Drafting the work and revising it critically for important intellectual content: MG, ZT

Literature review: $\mathrm{MG}, \mathrm{ZT}$

Writer: MG, ZT

\section{Declarations}

Conflict of interest The authors declare no competing interests.

\section{References}

1. Antonini A, Leta V, Teo J, Chaudhuri KR (2020) Outcome of Parkinson's disease patients affected by COVID-19. Mov Disord 35(6):905-908. https://doi.org/10.1002/mds.28104

2. Cilia R, Bonvegna S, Straccia G et al (2020) Effects of COVID19 on Parkinson's disease clinical features: a community-based case-control study. Mov Disord 35(8):1287-1292. https://doi.org/ $10.1002 / \mathrm{mds} .28170$

3. World Health Organization. Global surveillance for COVID-19 caused by human infection with COVID-19 virus: interim guidance, 20 March 2020. https://apps.who.int/iris/handle/10665/ 331506. Accessed 8 May 2020 
4. Erro R, Buonomo AR, Barone P, Pellecchia MT (2021) Severe dyskinesia after administration of SARS-CoV2 mRNA vaccine in Parkinson's disease. Mov Disord 36(10):2219. https://doi.org/10. 1002/mds. 28772

5. Brugger F, Erro R, Balint B et al (2015) Why is there motor deterioration in Parkinson's disease during systemic infections-a hypothetical view. NPJ Parkinsons Dis 27(1):15014. https://doi.org/10. 1038/npjparkd.2015.14

6. Helmich RC, Bloem BR (2020) The impact of the COVID-19 pandemic on Parkinson's disease: hidden sorrows and emerging opportunities. J Parkinsons Dis 10(2):351-354. https://doi.org/10. 3233/JPD-202038

Publisher's note Springer Nature remains neutral with regard to jurisdictional claims in published maps and institutional affiliations. 